\begin{abstract}
Given its close association with the formation of the Campaign for Nuclear Disarmament, it is tempting to assume that the response of Left intellectuals to the advent of atomic weapons was rooted in consistent opposition. This article demonstrates that the reality was much more complex. During the period of the US atomic monopoly (1945-1949) British Left intellectuals wrestled with the implications of this new destructive force and arrived at widely different understandings and prognoses. However, many shared a pessimism rooted in the belief that the atomic monopoly could not be maintained for long, that beyond this point the atomic future was unmanageable, and that it would result in future war and annihilation. Drawing on a range of British left-wing responses, and focusing in particular on those of Bertrand Russell and George Orwell, this article emphasizes the shifting nature and complexity of Left responses to the advent of the US atomic monopoly and analyses the circumstances in which these were arrived at. It shows that it is inaccurate to think in terms of a single or coherent left-wing position on atomic weapons at a time when many on the left believed further war to be inevitable and some believed that the only way to prevent it might lie in launching, or threatening, a preventive atomic attack on the Soviet Union.
\end{abstract}

KEYWORDS: LEFT, ATOMIC BOMB, ORWELL, RUSSELL, PREVENTIVE WAR 


\section{INTELLECTUALS OF THE LEFT AND THE ATOMIC DILEMMA IN THE AGE OF THE US ATOMIC MONOPOLY, 1945-1949}

\section{John Callaghan \& Mark Phythian}

\section{Introduction}

How did left-wing intellectuals in Britain respond to the advent of the atomic age? What did they understand its implications to be? Given its close association with the formation of the Campaign for Nuclear Disarmament, it is tempting to assume that the response of Left intellectuals was rooted in consistent opposition. This article demonstrates that the reality was much more complex. During the period of the US atomic monopoly (1945-1949), British Left intellectuals arrived at widely differing understandings and prognoses in the course of wrestling with the implications of this new destructive force. However, one common theme was pessimism rooted in the belief that the atomic monopoly could not be maintained for long, that beyond this point the atomic future was unmanageable and that it would result in atomic war. This article emphasizes the shifting nature of Left responses to the advent of the US atomic monopoly and focuses in particular on the responses of Bertrand Russell and George Orwell to illustrate the complexities involved in the British Left intelligentsia's consideration of the implications of the atomic age in this formative period. It demonstrates that it is inaccurate to think in terms of a single, or even coherent, leftwing position on atomic weapons at a time when many on the left believed further war to be inevitable and some believed that the only way to prevent it might lie in launching, or threatening to launch, a preventive atomic attack on the Soviet Union.

\section{The Gift of Destruction}

In the immediate aftermath of Hiroshima and Nagasaki the implications of a world with atomic bombs were widely debated by the British Left intelligentsia. The leftwing Labour weekly, Tribune, talked of a 'Race with Catastrophe' the day after the Nagasaki bomb. ${ }^{1}$ Only a week later, however, Tribune revised this judgment, talking instead of a 'shadow over the peace', owing to the redundancy of the old security measures and old strategic dispositions 'all over the world'. ${ }^{2}$ The new weapon conferred an 'almost unimaginable superiority of power' on its present owners assumed to be both the United States and Britain - 'over all other nations including 
the Soviet Union'. The Communist Daily Worker detected 'considerable public concern' about this monopoly. ${ }^{3}$ Tribune noted that those who thought another world war was inevitable 'rejoice in the Anglo-American monopoly', but added that the monopoly would prove short-lived, because it would only be 'a very short period of time' before the Soviet Union caught up. Rather than risk an arms race it would be better to share atomic knowledge and put the bomb under international control, as many on the left were demanding. ${ }^{4}$ When President Truman announced in the autumn of 1945 that the USA would keep the secret of the new technology, the New Statesman and Nation acknowledged that the statement 'was not unexpected'; it was, however, regrettable. The secret could be preserved 'at most only for a very few years' and if Truman expected that the bomb would help him in the game of power politics, the temptation to exploit this leverage would be all the greater in view of the monopoly's expected brevity. But it was already clear to the New Statesman that the psychology of inferiority and fear so evident in the behaviour of the Russians at the Council of Ministers' meetings was related to this monopoly. Once the monopoly was broken 'the competition may bring us in sight of a war of extermination. The American Century is not opening happily'. ${ }^{5}$

Similar points were made in the debate on the King's Speech which opened the new Parliament, with Morgan Philips Price, Labour MP for the Forest of Dean, questioning the wisdom of monopolizing the secrets of the atomic bomb and Ernest Bevin, the Foreign Secretary, suggesting that the problem's solution awaited developments in the United Nations. ${ }^{6}$ In November 1945 Truman and Attlee proposed a UN commission for the 'control' and 'elimination' of atomic weapons. A bill to control atomic energy was also put before the US Congress in December 1945 by Senator Brien McMahon. Until the UN's Atomic Energy Commission announced the suspension of its work in June 1948, hopes for international agreement lingered. But all prospects for an Anglo-American condominium in atomic matters were already dead by the time Truman signed the Atomic Energy Act on 1 August 1946, so radically had Congress altered the McMahon bill. The Labour Government responded by developing atomic weapons independently of the USA, though few members of the Cabinet knew of the decision. Secrecy may be part of the explanation for the 'extraordinary' lack of public discussion about Britain's development of atomic weapons during the Attlee period noted by Kenneth Morgan. ${ }^{7}$ But there is also little 
evidence of discussion of the bomb which already existed at the annual conferences of the Labour Party and Trades Union Congress before the Soviet Union acquired it. ${ }^{8}$ Even Denis Healey, who remembered being 'obsessed with the moral, political and military implications of nuclear weapons' very soon after the end of the war, did not write on the subject until the 1950s. ${ }^{9}$ Much of the public may have taken the view, as Tribune did in 1945, that Britain possessed the bomb already.

Many left-wingers had been involved, of course, in developing the bomb, some had even foreseen it, like H.G. Wells. In The War in the Air (1908) Wells already talked of atomic warfare. In his 1914 novel, The World Set Free, he explicitly predicted the coming of the atomic bomb and foresaw biological weapons of mass destruction. ${ }^{10}$ Wells also imagined a mid-century atomic war between opposing power blocs - the Free Nations and the Central Powers. But here his optimistic rationalism took over. ${ }^{11}$ There was little of that surviving in 1945, though Leo Szilard, the Hungarian-born theoretical physicist, remembered Wells at various points in his early musings on the subject of atomic energy. ${ }^{12}$ Schooled in Wells' apocalyptic visions, Szilard's first thought in response to the idea of splitting the atom was of the destructive potential of his theoretical insight. Wells remained a reference point for him at subsequent steps in the journey towards sustaining a chain reaction. ${ }^{13}$

Szilard was one of the first to realise, after 1933, the danger of Germany acquiring the knowledge to build atomic weapons. When war broke out this fear galvanised scientists and politicians working on the Manhattan Project. Some of them realised early on that the only defence against the new device would be deterrence possession of the bomb. Some of the scientists developing the bomb were Communists like Klaus Fuchs, Joseph Weinberg, David Bohm, and David Greenglass. Others with left-wing sympathies included Robert Oppenheimer, Theodore Hall and Oppenheimer's students Giovanni Lomanitz and Max Friedman. The Soviet Union's network of spies with access to atomic secrets included John Cairncross, Lord Hankey's private secretary, and the British scientist Alan Nunn May. Fuchs and Hall were among those who thought an American monopoly of the atom bomb was undesirable. ${ }^{14}$ Most were filled with foreboding when the bomb was finally used. 
Though few went as far as to call Hiroshima a war crime, ${ }^{15}$ the Second World War had demonstrated many things that were pertinent for the incipient atomic bomb debate. For some observers, America and Britain had made plain 'there are no limits to which we are not prepared to go for the sake of speedy victory'. ${ }^{16}$ But even a moralist like the missionary J. H. Oldham, honorary chair of the World Council of Churches, could see that it was a 'waste of time to preach liberal doctrines to men who are convinced that if they show mercy they will be ousted from power and forfeit their own lives’. He wasn’t thinking specifically of the men in the Kremlin, but rather of 'all those men, called statesmen, whose actions are chiefly determined by considerations of power politics'. ${ }^{17}$ It was necessary to adopt what he called an 'austere sincerity' and recognise that all of mankind was nearer to the gutter than it had been in September 1939; 'we have slipped down the scale of civilization without even being aware of the fact'. ${ }^{18}$ Only 'a revolutionary limitation of national sovereignty' could produce the inspection regime necessary to make international controls on atomic weapons possible. But simply to say this was tantamount to acknowledging its impossibility. Already there was alarming evidence that public opinion was reconciling itself to the inevitability of atomic warfare. ${ }^{19}$

As soon as the news of the Hiroshima explosion reached him, the eminent scientist and Communist J. D. Bernal, still working in Whitehall for 'the military machine', looked around at the Allied officers surrounding him and thought 'You are all finished - as out of date as the Yeomen of the Guard' ${ }^{20}$ The equally eminent J. B. S. Haldane, who wrote a regular popular science column for the Daily Worker, initially welcomed the bomb in the pages of the Communist Party's newspaper. ${ }^{21}$ He quickly changed his mind when it became evident that the wartime alliance had broken down. Writing in The Nation in September 1945, Bernal was more nuanced than Haldane, conceding that 'The immediate effects, however horrible, have been decisive in ending the war', but adding that 'the possibilities of further destructive use are in every man's mind and far more uncertain are the hopes that it may bring equally untold benefit.' 22 Truman's broadcast enjoining Americans to constitute themselves as 'trustees' of the new force had already reinforced Bernal's forebodings, for such a burden was, he thought, 'greater than can be borne by any government or group of governments. It is one that must be shared with the whole of the human race'. ${ }^{23}$ Attempts to control it by secrecy and by limitation were foredoomed to failure, only a 
fully international control under the guidance, in the first instance, of the UN would suffice. Along with Sir Henry Dale, President of the Royal Society, Bernal saw 'open dealings' about scientific discoveries as prerequisites for international control and the avoidance of permanent suspicion and the stifling of scientific initiative. ${ }^{24}$ Proliferation of atomic weapons was otherwise inevitable and existing levels of insecurity would simply rise if that was allowed to happen. By November 1945 Bernal was already predicting that 'soon bombs hundreds of times more powerful would be prepared'. ${ }^{25}$

The speed of the descent to pessimism was not confined to socialists of course. To contextualise these left-wing responses to Hiroshima let us look at the considered view of someone who was described as one 'who probably knows more of international relations and diplomacy in the twentieth century...than any other living historian'. ${ }^{26}$ In February 1945 Professor E. L. Woodward had been upbeat about the future of western civilization when he gave his inaugural lecture for the Montague Burton chair in International Relations at Oxford University. Eight months later, he admitted that Hiroshima had changed his 'and everyone’s mood'. ${ }^{27}$ The tragic view of history, he pointed out, predicted disaster even if politicians made the right moral choices in relation to this weapon. But the ‘type of revolutionary nihilism' recently displayed by the Nazis, which regarded destruction 'as a necessary prelude to any lasting improvement', was a reminder that a common moral code could not be assumed to exist. There was already enough evidence in the world to suggest that the threat was not confined to a few fanatics. Governments could succumb to nihilism in the future just as they had in the past. Woodward did not name the Soviet Union as a living example of this nightmare but others would do that for him.

Woodward's survey of the dangers represented by atomic bombs employed arguments repeated on the Left, but did so systematically. Civilization in the twentieth century was urban and the destruction of cities could now be contemplated on a scale which beckoned anarchy and darkness, from which we could no more recover than 'a finely bred dog' could survive in the jungle. History was filled, according to Woodward, with examples of over-confident risk-takers whose errors of judgment brought about their ruin; now they could bring about everyone's ruin. Only an equal balance of power and the certainty of effective and equal retaliation might prevent the 
use of atomic weapons, but even this was not proof against errors of calculation. In fact, there was every reason to expect that 'certain small or middle Powers' would acquire the bomb and thus multiply the risk that one of them, 'with less to lose, may well find it easier to think that the risks are worth taking' ${ }^{28}$

Woodward could envisage no effective antidote to the bomb and expected the secrets of its manufacture to spread quickly. He assumed that the costs of producing it would eventually fall, though not to the point where individuals could afford it. Governments would certainly want to acquire the device and would find the task easier as the application of atomic power to peaceful purposes was developed and spread. None of the four possible ways of guarding against atomic war offered any real prospect of security, Woodward argued. It was, in the first place, unsafe to assume that a policy of laissez-faire would lead to a balance of terror capable of permanently reducing the risk of war. Control by a single Power - the US - would give that power world sovereignty and a responsibility to ensure that no one else could manufacture the bomb. That would entail the US regarding any such attempts as an act of war punishable by immediate pre-emptive strikes. But why would other states concede this Leviathan role to the US and why would the citizens of the US want to accept it? Woodward could find no convincing answer to these doubts. The third clear-cut solution - a world government - was equally implausible, while (shades of Orwell's Nineteen Eighty-Four here) a half-way house of two or three federations spanning the globe 'would only increase our danger'. The final option - a special international organisation - met with the same basic objections; why would states cede this power in the first place and deny themselves profitable exploitation of atomic energy; why would they observe the convention once they had signed it; where would the international organisation be based; how could it be protected; how would an army of inspectors exercise effective vigilance over the whole globe, bearing in mind the probabilities of dispersed production, clandestine bargaining between governments, underground installations, and the ability to quickly assemble plant once the inspectors had left the scene of operations? And if all these objections were met, what was there to prevent the special international organisation from becoming a tyrannous Leviathan or a site of Great Power struggles that would eventually shrink its stature in the same way the League of Nations was shrunk before it? 
Woodward reflected the general pessimism among Left intellectuals in concluding that there was 'no hope of safety' in any of these clear-cut plans. There could be no fool-proof safety device against catastrophic destruction. For Woodward, only an approximation to security was possible. The sum of human misery seemed destined to increase, though commentators detected a certain short-term numbing of the popular mind in the autumn of 1945, attributable to war-weariness and incomprehension of the awesome power of the new weapons. Despite these emphases some socialists stressed that atomic technology was neither good nor bad in itself, but depended on how it was used by societies. Bernal did not fail to observe that the development of the bomb was the perfect illustration of an argument which he had honed since the 1920s. ${ }^{29}$ Great strides in human progress depended on a planned scientific effort that was preferably trans-national, even global, in scope and involved much greater expenditures of resources than science was accustomed to receive under capitalism. In other words, progress depended on socialism. The expenditure of $£ 500$ million on the Manhattan Project was probably greater than the amount spent on scientific discovery since the beginning of time, he told the Fabian Society in January $1946 .{ }^{30}$ The whole enterprise took only two years to complete and showed what could be achieved when market forces were suspended. But Bernal also told his Fabian audience - now just four months since Hiroshima - that the atomic bomb was 'the last word in terror weapons' - effective against cities and civilizations, but not a decisive military tool in its own right. Destroying German cities did not win the war in Europe and destroying Hiroshima and Nagasaki did not win the war against Japan; 'the Japanese were beaten before the atom bombs fell', Bernal asserted, echoing the view laid down by the Kremlin. ${ }^{31}$ What mattered now was the American folly of trying to maintain an atomic monopoly under conditions of secrecy inimical to science, progress and peace:

The one party concerned may think that he represents goodness and impartial authority and everybody else represents crime, but I think you will recognise that even if that were true it would still be a dangerous policy...the arbitrary use of a weapon in the hands of one party is a standing invitation for its use by other parties under the most undesirable conditions of rivalry and secrecy. ${ }^{32}$ 
Worsening relations between the USA and the Soviet Union undoubtedly informed Bernal's perception that the only effective answer to the atom bomb was 'the condition of peaceful interrelations of nations'. His arguments also reflected the Soviet refusal to be intimidated by the bomb or allow its use to eclipse their own massive contribution to the defeat of the Axis. Like other Communists, Bernal was now concerned that an atmosphere of suspicion and insecurity could create the state of mind again which made using the atomic bomb thinkable. Ruthlessness and inhumanity had been tolerated even 'by our own people' in the world war; if the public could be conditioned to regard other peoples as 'subhuman' the bomb could be used again. It was more than ever necessary to prevent 'any kind of international and inter-racial attitude of contempt, fear or hatred'. ${ }^{33}$ Yet in a BBC broadcast of March 1946 Bernal already saw this prospect taking hold: 'The real danger does not come from the Soviet Union, or the atom bomb, or from the inherent wickedness of man...It comes from those who...have discovered the special values of "western civilization", the defence of which we can now take up from the defeated Germans. ${ }^{34}$ A letter leaked to the press in September 1946 would confirm Bernal's fears. It showed that Henry Wallace, Truman's Secretary of Commerce, had complained to the President that 'certain unnamed members of the US military command were advocating a "preventive war" before Russia had time to develop an atomic bomb. ${ }^{35}$

The British physicist Alan Nunn May had been supplying the Soviet Union with atomic intelligence since the early summer of 1945. Theodore Hall and David Greenglass - the latter through Julius Rosenberg - were doing the same. Before the end of the year Klaus Fuchs informed the Russians that the Western Allies were already in dispute about access to atomic secrets and, concerned that the Russians were being depicted as the next enemy, he declared himself even more determined to help them. Lavrenti Beria received a consolidated report based on these clandestine sources in October $1945 .{ }^{36}$ In December McMahon's Bill began its journey through Congress, leading to a unique prohibition on free speech in America - a complete ban on the dissemination of technical data related to atomic energy.

As the Soviet Union emerged as a sinister contender for world domination, the US talked of international control of atomic weapons. Secretary of State James Byrnes raised this possibility at the Moscow Council of Foreign Ministers in December 1945 
and the meeting agreed on the establishment of a UN commission for the control of atomic energy. But doubts were immediately raised. Oppenheimer persuaded an internal Board of Consultants - chaired by David Lilienthal on Byrnes' ultimate authority - that nothing short of an international monopoly, under UN auspices, of the entire atomic industry would suffice, coupled with global proliferation of atomic technology to create the conditions for effective deterrence. As Baggott observes 'It was an astonishingly bold proposal, containing more than a whiff of scientific and technological socialism'. ${ }^{37}$ The proposals were published as the Acheson-Lilienthal Report in March 1946 just as scientists like Einstein and Szilard contributed One World or None warning the public of the dire consequences of atomic warfare. By this time, however, Truman and Churchill were equally convinced that the Soviet Union was not interested in diplomacy and had to be confronted on a global scale.

In this context the Acheson-Lilienthal Report fell still-born from the press. Truman turned to Bernard Baruch, a presidential adviser in both world wars, who produced an alternative plan in June 1946 proposing managerial control of all dangerous atomic energy activities and the dismantling of existing stockpiles of atomic weapons when an effective way had been found to police them internationally. Stalin was required to renounce any attempt to acquire his own bomb and defer to an international authority with real powers of inspection and punishment. In the meantime the Americans would keep their atomic monopoly. The Russians rejected the Baruch Plan by countering it with a proposal that states police themselves as they already did in respect of chemical weapons.

\section{Russell and the Defence of Civilization}

Bertrand Russell was one of the prominent left-wing supporters of the Baruch Plan in Britain. The defence of civilization was a standpoint he had taken in the past - it informed his opposition to the Great War - and one he adopted now in the context of the American atomic monopoly. Russell had a deserved reputation as an opponent of war. This had been his stance in 1914-18, and at personal cost. It took until 1940 before he came to the conclusion that Hitler could only be stopped by force, so convinced had he been that force, or threats of force, would only encourage the fears which had promoted Hitler in the first place and bring a catastrophic war nearer. 
Russell, then, was no war-monger. But he had been remarkably clear-eyed about the Bolshevik dictatorship since his visit to Soviet Russia in 1920 and never diverted from the views he expressed about it then - namely that it was a cruel and violent dictatorship. $^{38}$ During the Second World War he expressed regret that Stalin's dictatorship might survive it, declaring that it was even worse than Hitler's. Less than a month after the dropping of the bombs on Japan, he privately wrote:

I see very little hope for the world. There is no point in agreements not to use the atomic bomb, as they would not be kept. Russia is sure to learn how to make it. I think Stalin has inherited Hitler's ambition for world dictatorship. One must expect a war between USA and USSR, which will begin with the total destruction of London. I think the war will last 30 years, and leave a world without civilized people, from which everything will have to be built afresh - a process taking (say) 500 years. $^{39}$

As his biographer remarks, 'the apocalyptic vision of civilisation destroying itself through the power of its science and technology, which Russell had expressed in countless articles and books since the 1920s, now looked prophetic'. ${ }^{40}$ In August 1945 he said publicly, echoing the thoughts of Szilard and Einstein, that 'the prospect for the human race is sombre beyond all precedent. Mankind are faced with a clearcut alternative: either we shall all perish, or we shall have to acquire some slight degree of common sense. ${ }^{41}$ Russell thought it fortunate that the USA possessed an atomic monopoly, but knew that the situation would not last long. Fearing, like many others, that an independent international authority in sole control of uranium was a utopian fancy, Russell argued that:

If America were more imperialistic there would be another possibility, less Utopian and less desirable, but still preferable to the total obliteration of civilized life. It would be possible for Americans to use their position of temporary superiority to insist upon disarmament, not only in Germany and Japan, but everywhere except in the United States, or at any rate in every country not prepared to enter into a close military alliance with the United States, involving compulsory sharing of military secrets. During the next few 
years, this policy could be enforced; if one or two wars were necessary, they would be brief, and would soon end in decisive American victory. In this way a new League of Nations could be formed under American leadership, and the peace of the world could be securely established. But I fear that respect for international justice will prevent Washington from adopting this policy. ${ }^{42}$

The next month he was warning of the need for the USA to impose its will on the international situation and to avoid appeasing Moscow. Privately he thought war between the former allies was more likely. Russell did not lag behind Western politicians in his fear of Stalin's aggression and his desire for American leadership so when the Soviet Union rejected the Baruch Plan in June 1946 he openly advocated the threat of war to secure Moscow's future adherence to the scheme. Throughout the period 1945-8 his arguments were informed by fear of Soviet expansion in Western Europe as well as fear of an atomic war following Russia's development of the bomb. $^{43}$

Like other Left intellectuals Russell's political analysis of the atomic bomb was bound up inextricably with his view of Stalin's Soviet Union. Along with George Orwell and Arthur Koestler, Russell's view of the Soviet Union was grim. In a November 1947 letter, for example, he confided to Albert Einstein that he had 'no hope of reasonableness in the Soviet Government. ${ }^{44}$ Russell shared Orwell's belief that the Soviet Union could not be trusted. In correspondence Russell argued 'There is one thing, and one only, which could save the world, and that is a thing which I should not dream of advocating. It is that America should make war on Russia during the next two years, and establish a world empire by means of the atomic bomb. ${ }^{45}$ Publicly he asserted that the threat of war would suffice. In a letter to Einstein he adopted this stance: 'I think the only hope of peace (and that a slender one) lies in frightening Russia. I favoured appeasement before 1939, wrongly, as I now think; I do not want to repeat the same mistake., 46

Faced with the threat of atomic war, Russell expected the Soviet Union to comply and accept the US atomic monopoly. However, the logical distance between advocating threats and supporting a pre-emptive strike if the Soviets refused to yield (as Russell 
himself believed) was never a great one. The context of mounting fear of the Soviet Union's intentions is indicated by the strident anti-Communist content of the leftwing Tribune journal, associated with the Labour Party left-wing, after Soviet rejection of the Marshall Plan. Socialists who had advocated co-operation with Stalin in 1945-6 were now convinced that only confrontation would suffice. ${ }^{47}$ In a May 1948 letter to Dr. Walter Marseille at the University of Berkeley, Russell's fears received their strongest expression:

If Russia overruns Western Europe, the destruction will be such as no subsequent re-conquest can undo. Practically the whole educated population will be sent to labour camps in North-East Siberia or on the shores of the White Sea, where most will die of hardships and the survivors will be turned into animals. (Cf. what happened to Polish intellectuals taken to the Soviet Union in 1939.) Atomic bombs, if used, will at first have to be dropped on Western Europe, since Russia will be out of reach. The Russians, even without atomic bombs, will be able to destroy all big towns in England, as the Germans would have done if the war had lasted a few months longer. I have no doubt that America would win in the end, but unless Western Europe can be preserved from invasion, it will be lost to civilization for centuries.

Even at such a price, I think war would be worth while. Communism must be wiped out, and world government must be established...I do not think the Russians will yield without war. I think all (including Stalin) are fatuous and ignorant. But I hope I am wrong about this. ${ }^{48}$

Between 1945 and 1948 Russell publicly advocated threatening Russia with war in order to coerce her to accept international control of nuclear weapons on a dozen separate occasions. ${ }^{49}$ Clearly this high risk stance, were it adopted, meant war if the Russians refused to comply. In the letter to Marseille Russell is adamant that such a war would be worthwhile, concluding that 'Communism must be wiped out, and world government must be established...I do not think the Russians will yield without war'. ${ }^{50}$ Marseille understood this to mean that Russell was advocating preventive war and close examinations of Russell's work agree on this interpretation. ${ }^{51}$ The matter did not remain private - already in November 1948 Russell was complaining to The Observer that he had not advocated preventive war, as had been reported, in a speech 
at Westminster School; ${ }^{52}$ in 1951 his lawyers insisted that the New Statesman publish a long refutation of Kingsley Martin's contention that Russell had urged preventive atomic war; ${ }^{53}$ finally, his 1948 correspondence with Walter Marseille was given a fresh airing when it was published by the latter in The Saturday Review on $16^{\text {th }}$ October 1954. Russell was clearly embarrassed by his militant line but it seems to have accurately reflected his thinking in 1948 as others who communicated with him at that time attested - such as Gilbert A. Harrison, the editor of the New Republic. ${ }^{54}$

\section{George Orwell's Atomic Dilemma}

Russell abandoned the argument that the threat of war would bring the Soviet leaders to their senses and contented himself after 1948 with demands that any acts of Soviet aggression should be met militarily. But some questioned the idea that the Soviet Union was the aggressor. And it was not only Communists and those suspected of being crypto-Communists like the Labour MP Konni Zilliacus ${ }^{55}$, who saw America's possession of the bomb as a big stick with which to beat the Russians. Patrick Blackett in 1948, the year he won the Nobel Prize for physics, argued that the very decision to use atomic weapons against Japan had been taken for political reasons, rather than military, to secure a favourable balance of power for the USA against the Soviet Union; 'it was a clever and highly successful move in the field of power politics...the first act of the cold diplomatic war with Russia now in progress'. ${ }^{56}$ Likewise the Baruch Plan, Soviet compliance with which had so exercised Russell, was simply a 'victory for American diplomacy' rather than a serious attempt to solve the problem of atomic weapons. The Russians had been offered little more than subservience cleverly packaged as a wise and generous measure. ${ }^{57}$ Notwithstanding Blackett's prestige as both a socialist and a scientist, these views made little impact in 1948 and 1949, years when even Tribune was wholly convinced that the Soviet Union was the principal aggressor in world politics and the main threat to peace.

No one did more than George Orwell among British socialists to expose the deceptions and reality of the Soviet Union. Animal Farm and Nineteen Eighty-Four were among the most effective contributions to the cultural Cold War unfolding before Orwell's death in January 1950. The latter was written in the shadow of the new doomsday device. Yet, whereas H. G. Wells' fiction involved substantial 
engagement with the potential horrors of atomic war, Orwell, Wells' successor in some ways, is largely silent on this aspect of the problem. Highly sensitive to, and frequently depressed by, the dangers of a post-1945 atomic war, Orwell devoted only a few of his journalistic writings to atomic weapons, and although an atomic exchange preceded the emergence of totalitarian rule in Nineteen Eighty-Four, as an element of the plot it is peripheral. The same was true of William Golding's Lord of the Flies (1954). In both cases atomic war was arguably an inessential component of what they were trying to say and Golding was persuaded to delete all reference to it in the published version of his best-seller. The difference is that Orwell was preoccupied in all of his work in the 1940s with the shape of political things to come. Atomic weaponry had to figure somewhere in these ruminations.

The period surrounding the use of the atomic bombs on Japan was a highly significant one for Orwell as a writer. After a tortuous passage, Animal Farm was finally published on $17^{\text {th }}$ August 1945 and, for the most part, Orwell's surviving correspondence of the period is understandably taken up with issues relating to the novel. However, in July 1945 he wrote an article for the magazine Junior, published by Children's Digest Publications Ltd. To this he added a short introductory paragraph in the wake of Hiroshima, representing his first comment on the atomic bomb. In terms of Orwell's evolving vision of the emerging Cold War, it is the main body of the article that is of most interest. Anticipating the Cold War emergence of opposing power blocs, Orwell wrote that:

Today most of the small nations are unable to produce modern weapons, even in small quantities. High-speed aeroplanes, or large-calibre guns, or pieces of armour plate big enough for battleships, can only be produced in the main industrial areas, of which there are about a dozen in the whole world. It follows that every small nation has to live under the protection, and to some extent under the control, of some big nation, usually its nearest neighbour. ${ }^{58}$

Foreseeing the emergence of the bi-polar division of the global map, Orwell went on: 'The world will split into three camps, and ultimately into two, for Britain, not strong enough to stand alone, will become part of the American system. The smaller nations will be grouped about the bigger ones. ${ }^{59}$ Russell had reached similar conclusions 
about Britain's looming dependency on the US in the 1920s, though his emphasis then had been economic and ideological.

Orwell next mentioned the atomic bomb in a coda to his regular 'London Letter' for the US Partisan Review journal, penning two final paragraphs after news of Japan's surrender had reached Britain:

The news of the Japanese surrender came in yesterday about lunchtime, when I was in Fleet Street. There was quite a bit of jubilation in the streets, and people in upstairs offices instantly began tearing up old papers and throwing them out of the window...The prompt surrender of Japan seems to have altered people's outlook on the atomic bomb. At the beginning everyone I spoke to about it, or overheard in the street, was simply horrified. Now they begin to feel that there's something to be said for a weapon that could end the war in two days. Much speculation as to "whether the Russians have got it too." Also, from some quarters, demands that Anglo-America should hand over the secret of the bomb to Russia, which does seem to be carrying trustfulness a bit far. ${ }^{60}$

Is it possible to divine anything of Orwell's thinking at the time from this seemingly innocuous paragraph? Certainly, it raises questions. Are the people he speaks to, as distinct from those he overhears on the street, drawn from the group of writers and intellectuals he was linked to? Does this represent something of their thinking? Although Orwell is reporting their thoughts, does he share them? Not necessarily, one may think, although in the final sentence in which he reports sentiments he disagrees with - such as the calls to share atomic secrets with the Soviet Union - he is quick to distance himself from any such initiative.

Did Orwell, then, ultimately support the use of the atomic bomb over Japan? There is no direct evidence either way. Certainly, Orwell was no pacifist. His commitment to individual liberty at a societal level, underpinned by an opposition to the coercive power of the modern state, coexisted alongside a recognition that at the international level: 'The whole theory of pacifism, if one assumes it to mean outright renunciation of violence, is open to very serious objections. It is obvious that any Government that is unwilling to use force must be at the mercy of any other Government, or even of 
any individual, that is less scrupulous - so that the refusal to use force simply tends to make civilised life impossible. ${ }^{61}$ Moreover, in a review of Basil Liddell Hart's The Revolution in Warfare, Orwell could not bring himself to agree with Liddell Hart's criticism of the recent allied bombing of civilian targets in Germany. ${ }^{62} \mathrm{~A}$ realist appreciation of the role of power in world politics would seem to have informed his view of world politics.

The only piece of journalism Orwell ever penned that was devoted exclusively to the atomic bomb was 'You and the Atom Bomb', published in Tribune in October 1945. This is significant for its early outline of what in a more developed form would come to be known as Mutually Assured Destruction (MAD). Hence, we can credit Orwell with understanding at the outset what some neo-realists would later claim - and by luck or design proved to be the case - that a bipolar nuclear world would be essentially stable. While many of Orwell's political predications were hopelessly offbeam (partly a consequence of being so attached to prediction in his journalism), this is impressive in that just a matter of weeks after the first use of the atomic bomb Orwell was able to accurately project the probable logical consequences of the spread of atomic know-how:

From various symptoms one can infer that the Russians do not yet possess the secret of making the atomic bomb; on the other hand, the consensus of opinion seems to be that they will possess it within a few years. So we have before us the prospect of two or three monstrous super-States, each possessed of a weapon by which millions of people can be wiped out in a few seconds, dividing the world between them. It has been rather hastily assumed that this means bigger and bloodier wars, and perhaps an actual end to the machine civilisation. But suppose - and really this is the likeliest development - that the surviving great nations make a tacit agreement never to use the atomic bomb against one another? Suppose they only use it, or the threat of it, against people who are unable to retaliate? In that case we are back where we were before, the only difference being that power is concentrated in still fewer hands and that the outlook for subject peoples and oppressed classes is still more hopeless. ${ }^{63}$ 
This also clearly represents an early vision of the global configuration of power that would hang over the three rival power blocs in Nineteen Eighty-Four, on which Orwell was already making notes by this time. Orwell also drew attention to the social implications of such an atomic stand-off - and this is the very substance of Nineteen Eighty-Four. Such a stand-off would produce stability by virtue of the need for loyalty, order, and alertness to the threat posed by the 'other'; the degree of threat faced would legitimise the degree of unity and surveillance required by the state. Early on then, Orwell raised the question of the 'kind of world-view, the kind of beliefs, and the social structure that would probably prevail in a State which was at once unconquerable and in a permanent state of "cold war" with its neighbours. ${ }^{64}$ His focus was never solely on the destructive potential of the atomic bomb. He also focused on its implications for the state power - individual liberty trade-off. Not only did Orwell show an acute early understanding of the strategic implications of the possession of the atomic bomb, he also, almost in passing, provided the term 'cold war' to define the 40-odd year period of atomic confrontation, (in advance of people like Walter Lippman and Bernard Baruch, usually credited with its origin).

Orwell's revulsion at the potential destructive power of atomic weapons was highlighted in a subsequent Tribune piece, 'What is Science?', in which he contrasted favourably the refusal of some American and British physicists to contribute or continue with the Manhattan Project, with the continued co-operation of those who worked on it. These were, he told Tribune readers, 'sane men in the middle of a world of lunatics. ${ }^{65}$ His distaste for certain men of science - 'power-hungry' scientific materialists like Bernal among them - would surface again. ${ }^{66}$ Still, by year's end Orwell appeared confident that the US could guard the secret of the bomb. Even by this time there is a sense that, for Orwell, the threat posed by the bomb would only become a factor once the Soviet Union acquired it. In addition, he predicted that in, 'all countries the general public will gradually lose interest in the subject." ${ }^{67}$ This was worrying because the understandable popular desire to return to normality was mixed up with a certain fatalism:

The notion that a war between Russia and America is inevitable within the next few decades, and that Britain, in its unfavourable geographical position, is bound to be blown to pieces by atomic bombs, is accepted with a sort of vague 
resignation, rather as people accept the statement that sooner or later the sun will cool down and we shall all freeze to death. The general public seems to have forgotten about the atomic bomb, which seldom figures in the news. Everyone is intent on having a good time, so far as our reduced circumstances permit. $^{68}$

For Orwell as for Russell, the question of the atomic bomb was intimately bound up with his assessments of Soviet intentions, leadership and society. Relatively sanguine about US possession of the bomb, as his anti-communism became a more pronounced element of his journalism after 1945 so his thinking on the bomb was increasingly linked to likely Soviet behaviour. As a consequence his earlier confidence in the stability of a bi-polar nuclear world was undermined. One reason for this can be traced to the impact on Orwell's thinking of James Burnham's writings. Both men wrote for Partisan Review and Burnham's The Managerial Revolution provided much of the inspiration for the framework of Nineteen Eighty-Four. In 1947 Burnham's The Struggle for the World was published. In this Burnham, a former Trotskyist and academic who had spent the war years working for US intelligence, asserted that the Third World War had already begun. It was being fought globally by international Communism against the free world. The Communist camp was depicted as rational, focused, united, ruthless and ideologically-driven, while America was portrayed as politically naive, inconsistent and inept, driven by little more than 'a powerful urge towards a crude, narrowly conceived economic imperialism'. ${ }^{69}$ Burnham foregrounded the creation of the atomic bomb in his book's main argument and Orwell could see that he was 'demanding, or all but demanding, an immediate preventive war against Russia’. Burnham stressed that the American monopoly would not last long; that the bomb threatened total annihilation of human life; that Western Civilization was most vulnerable to atomic warfare; that fear would cause bombs to be used unless a monopoly could be maintained; that only the US and the Soviet Union were serious candidates to possess this monopoly. Orwell summarised Burnham's argument: 'When weapons have reached this level of deadliness, one cannot take the risk of letting the enemy get his blow in first, so that as soon as two hostile nations possess atomic bombs, the explosion will follow almost immediately. In Burnham's opinion, we have perhaps ten years, but more probably only five, before the third world war.' Burnham's aim, Orwell continued, 'is to urge the United States 
to seize the initiative and establish what amounts to a world empire now, before Communism swallows the whole of Eurasia. The actual continuity of civilisation, he says, is threatened by the existence of atomic weapons, and there is no safeguard except to make sure that only one nation possesses them. ${ }^{, 70}$ Orwell could see a certain logic in this, even while making clear it was not his preferred option. Burnham, he wrote:

is certain to be denounced as a warmonger for writing this book. Yet if the danger is as acute as he believes, the course he suggests would probably be the right one: and more than this, he avoids the usual hypocritical attitude of "condemning" Russian policy while denying that it could be right in any circumstances to go to war. In international politics, as he realizes, you must either be ready to practice appeasement indefinitely, or at some point you must be ready to fight. ${ }^{71}$

This raises the question of whether Orwell himself believed the danger to be as acute as Burnham suggested it was? We know that Russell agreed with the main deductions in Burnham's analysis. Orwell certainly argued that 'Unless the signs are very deceiving, the USSR is preparing for war against the Western democracies. Indeed, as Burnham rightly says, the war is already happening in a desultory way. ${ }^{72}$ However, this did not mean that Burnham's timescale was accurate, or that he was right about the Soviet Union's strength, when so little was known about the extent of the devastation it had suffered in the war. If there was more time available Orwell's preferred solution was to make democratic socialism work: 'If one could somewhere present the spectacle of economic security without concentration camps, the pretext for the Russian dictatorship would disappear and Communism would lose much of its appeal. But the only feasible area is Western Europe plus Africa. ${ }^{, 73}$ How this example would disarm the Soviet state remained unclear; in any event it could only work in the longer run and had little purchase on the immediate situation.

Orwell's clear rejection of a pre-emptive strike on the Soviet Union is outlined in a summer 1947 piece for Partisan Review in which he sketched out possible scenarios for world politics. The first was the pre-emptive strike option. 'This would solve nothing', Orwell wrote. 'It would do away with the particular danger that is now 
presented by the USSR, but would lead to the rise of new empires, fresh rivalries, more wars, more atomic bombs, etc.' Leaving no room for any doubt as to his views, he wrote that in his view 'a preventive war is a crime not easily committed by a country that retains any traces of democracy. ${ }^{, 74}$ Orwell's second scenario involved a continuation of the Cold War until the Soviet Union and possibly other states possessed the atomic bomb, followed by a war that would leave the world in preindustrial chaos. He remarked wryly that 'Conceivably this is a desirable outcome, but obviously it has nothing to do with socialism. ${ }^{75}$ The third scenario - the MADinspired Cold War stability he had anticipated in 1945 - he regarded as 'the worst possibility of all' because of the societal implications for life within the atomic blocs the grim subject of the manuscript he was then working on:

It would mean the division of the world among two or three vast superstates, unable to conquer one another and unable to be overthrown by any internal rebellion. In all probability their structure would be hierarchic, with a semidivine caste at the top and outright slavery at the bottom, and the crushing out of liberty would exceed anything that the world has yet seen. Within each state the necessary psychological atmosphere would be kept up by the complete severance from the outer world, and by a continuous phoney war against rival states. $^{76}$

What is increasingly clear from both Russell's and Orwell's journalism of this time is their Cold War pro-Americanism. Orwell's thinking on the role of atomic weapons in the emerging Cold War during this period was also, as the foregoing indicates, an evolving one, dealing in alternatives and changing scenarios rather than singular solutions or static analyses. Attempts to portray Orwell as being uniformly in opposition to everything James Burnham wrote, partly out of recognition of Burnham's subsequent Cold War trajectory (culminating in his being awarded the Orwellian-sounding Medal of Freedom by Ronald Reagan in 1984), as Christopher Hitchens does in Orwell's Victory, are simply inaccurate. ${ }^{77}$ Orwell engaged with Burnham seriously, writing balanced and lengthy commentaries on him. While he disagreed with many of his speculations and much of his analysis, there were elements he found himself able to agree with. Orwell's treatment of works he simply disagreed with tended to state this disagreement concisely and unambiguously. 
Burnham's impact on Orwell is much more complex than superficial treatments suggest, as was Orwell's approach to atomic questions. Yet, of Orwell's principal biographers only Bernard Crick is alive to the political and intellectual dilemma Burnham's writings created for Orwell. ${ }^{78}$

Burnham's break with Trotsky in 1937 had been occasioned by his realisation that a land of labour camps and mass repression, as Trotsky himself depicted it, was no kind of 'workers' state', not even the degenerated workers' state which Trotsky insisted it was. The monstrous Stalin dictatorship and its global reach loomed ever larger in Burnham's catastrophic sensibility. Orwell travelled by a similar path, though ever alert to Burnham's fascination with power, and more sanguine about the prospects for democratic socialism. But if, in the absence of a viable pan-European socialist alternative, Britain had to make a Cold War choice between aligning with the US or the Soviet Union, Orwell - like Russell - was as unequivocal as Burnham about the choice: 'It will not do to give the usual quibbling answer, "I refuse to choose." In the end the choice may be forced upon us. We are no longer strong enough to stand alone, and if we fail to bring a western European union into being, we shall be obliged, in the long run, to subordinate our policy to that of one Great Power or the other. And in spite of all the fashionable chatter of the moment, everyone knows in his heart that we should choose America. ${ }^{79}$

In the last 18 months of his life Orwell became increasingly convinced that atomic war was inevitable once the Soviet Union possessed the bomb. In part this changing mood is attributable to the course of the Cold War since June 1947, as it was for Russell. Thus it became widely accepted that 'atomic bombs were particularly suitable for aggressors and unprovoked surprise attacks', as convenient for an ideologically-driven dictatorship as they were alien to Anglo-American constitutional and military practice, a point Burnham had not failed to stress. ${ }^{80}$ But Orwell’s outlook also became bleaker as his health deteriorated and the manuscript of Nineteen EightyFour reached completion. He opened his mid-1948 essay on George Gissing by noting that: 'In the shadow of the atomic bomb it is not easy to talk confidently about progress. However, if it can be assumed that we are not going to be blown to pieces in about ten years' time, there are many reasons, and George Gissing's novels are among them, for thinking that the present age is a good deal better than the last one. ${ }^{81}$ In an 
October 1948 letter to David Astor he wrote that he supposed 'the atomic war is now a certainty within not very many years. ${ }^{82}$ Later the same month he wrote to Julian Symonds, discussing his adopted son, Richard, and the prospect of his future education at Eton, before returning to the omnipresent atomic threat: 'Of course we may all have been blown to hell before it becomes urgent, but personally I don't expect a major shooting war for 5 or 10 years. ${ }^{, 83}$ He may have disagreed with James Burnham over the timescale and the urgency of a pre-emptive strike, but along with Russell they shared a belief in the trigger for war: 'After the Russians have fully recovered and have atomic bombs, I suppose it isn't avoidable. ${ }^{, 84}$

Communist assumptions were symmetrical with those of Orwell. Bernal himself gave the Daily Worker the Orwellian idea in 1948 that, as 'terror weapons', atomic bombs were being used 'in order to fascinate and frighten the people of all countries, including those of England and America, from daring to oppose in any way the policies that their rulers have determined'. ${ }^{85}$ The danger of war, of course, came from the West in this view. The Daily Worker reported Churchill, in a parliamentary speech, recommending the use of the atomic bomb before Russia had the chance to acquire it. ${ }^{86}$ By the beginning of 1948 the Communists had embarked upon a markedly anti-American campaign in response to the lead given by the Soviet Union in September 1947, when the Communist Information Bureau (Cominform) was launched in Poland. The central theme of this campaign, however, was US imperial domination of Britain, not the US monopoly of atomic weapons or the danger of an American pre-emptive strike against the Soviet Union. The threat of atomic bombs caused less alarm in Moscow, to judge from these polemics, than the cultural corruption represented by Hollywood and American comic books. ${ }^{87}$ The famous Soviet-inspired peace campaign, giving rise to the Stockholm Appeal of March 1950 for an absolute ban on nuclear weapons, can be traced back to a Polish-French initiative of August 1948. But even this earlier date is a leisurely 12 months behind the marked deterioration in superpower relations that followed the proclamation of the Truman Doctrine and announcement of Marshall Aid. Peace became a dominant motif in Communist campaigning only after the Soviet Union tested its own bomb in August 1949. 


\section{Conclusions}

The British socialist Left is closely associated with the Campaign for Nuclear Disarmament which was launched in February 1958, with Russell as one of its leading figures. Once both superpowers possessed thermonuclear devices Russell was persuaded that the defence of civilization was jeopardised by the Cold War and the arms race and, in common with most of the left-wing of the Labour Party, called for disarmament and detente. During the period of the American atomic monopoly, however, when thinking and anxiety about atomic weapons was still new, it is clear that many socialists, Russell included, saw the main danger emanating from Moscow. This is a reminder that the fear of the Soviet Union expressed in many public utterances by leading politicians was felt also on the Left, even by men as suspicious and sceptical of the political mood of the moment as Russell had always been.

But we are also reminded that in the brief period of the American monopoly a range of views coexisted on the meaning of atomic weapons within the British Left. There was a belief that they had shortened the war and saved lives, as well as dread that they had come into existence and profound pessimism as to their future control. Some asserted that they had rendered the old military technologies and thinking redundant, while others denied that they made a decisive difference to these questions. Winston Churchill told an audience at MIT in March 1949, that 'Europe would have been Communised and London under bombardment some time ago but for the deterrent of the atomic bomb in the hands of the United States' ${ }^{88}$ This line of reasoning carried weight. But Communists were not alone in thinking that the world would be a safer place if an atomic balance was achieved by Soviet possession of the new weapon. Proliferation was in any case expected, as was the development of ever more powerful devices.

The dominant view on the Left, however, was fear of Moscow's acquisition of the bomb. In Russell's view it could mean war and a major set-back for, if not the complete destruction of, civilisation. Such fears could make pre-emptive war, or the threat of war, against the Soviet Union seem a relatively attractive option. Orwell, more consistently preoccupied by the evils of the Soviet and Communist system than most socialists, rejected such reasoning. In 'Why I Write' he explained how: 'Every 
line of serious work that I have written since 1936 has been written, directly or indirectly, against totalitarianism and for democratic Socialism, as I understand it. ${ }^{89}$ In a sense, the atomic bomb was also against totalitarianism for as long as only the US possessed it. For Orwell, Russell and Burnham, its real threat lay in the period that would follow Soviet acquisition. The time remaining before World War III was essentially limited by the time this process would take. Yet Orwell rejected preemptive war and he did so, at least in part, because he believed in the possibility of a democratic socialist alternative, more attractive than Communism, and he doubted the veracity of Burnham’s depiction of Soviet and Communist strength:

One ought not to think of the Soviet Government as controlling in every country a huge secret army of fanatical warriors, completely devoid of fear or scruples and having no thought except to live and die for the Workers' Fatherland...if Stalin really disposed of such a weapon as that, one would be wasting one's time in trying to resist him. ${ }^{90}$

In doing so Orwell cast doubts on a particular version of totalitarianism which did much service in the Cold War - that of an ideologically-driven state with total command of its people and resources.

The news that the Soviet Union had acquired atomic bombs 'changed nothing', asserted Tribune on 30 September 1949: 'Nothing essential has changed - except from the point of view of that handful of people who wanted to forestall the event by a preventive war against Russia'. ${ }^{91}$ And yet by the journal's own reasoning this was untrue. The Western Powers had rejected calls for the destruction of existing stocks of atomic weapons until a foolproof system of international control, inspection and enforcement could be devised. The Russians, for their part, were 'not likely ever to agree to such a system of international inspection and sanctions' because their 'tightly regimented social and political system' had to be protected 'from any dangerous contact with the uncontrollable outside world. No country which has so much to hide as Russia and whose propagandist claims...are so grossly at variance with the facts can agree to an international control system which would inevitably become a medium of exposure'. All this pointed to an arms race. The New Statesman acknowledged the demise of the preventive war doctrine, adding that preparedness for 
war now meant that the state 'must be permanently and totally organised for war', much as Orwell depicted the world of Nineteen Eighty-Four. This would be prohibitively expensive 'unless Mr Truman and Mr. Stalin are prepared to transform their countries'. The socialist journal thought this to be unlikely because even the men in the Kremlin would not want to ruthlessly subordinate consumption to the needs of national defence for ever. ${ }^{92}$ The incentives for disarmament and international controls as demanded by Dean Acheson at the UN were stronger than ever, it concluded. And yet it was only a matter of months before Truman announced his intention to develop hydrogen bombs. Soon winnable wars using nuclear weapons were credible again for public intellectuals - some of them notable men of the Left. ${ }^{93}$

1 'Race with Catastrophe', Tribune, 10 August 1945, pp.1-2.

2،Shadow over the Peace', Tribune, 17 August 1945.

${ }^{3}$ Daily Worker, 13 August 1945. Harold Laski voiced similar concerns in his Chairman's Address to the Labour Party annual conference. See Labour Party Annual Conference Report (London, Labour Party 1946), p. 66.

4 'Shadow over the Peace', p.2; see also H. N. Brailsford in Reynold's News, 10 August, 1945; editorial in Plebs, September 1945, p. 2; 'Speak for England', New Statesman and Nation, editorial, 18 August 1945, p.1.

5 ‘Atomic Democracy’, New Statesman and Nation, 13 October 1945, p.239.

6 'Spotlight on Westminster', Electrical Trades Journal, volume 34, 9, September 1945, p. 267. Clement Attlee also looked to the United Nations in his speech to the United Nations Association meeting at the Albert Hall ahead of the UN's first meeting in December 1945. See R. B. Suthers, 'Of a Number of Things', NATSOPA, volume 29, number 341-43, October-December, 1945, p. 23.

${ }^{7}$ Kenneth O. Morgan, Labour in Power, 1945-51, (Oxford, Oxford University Press, 1984), fn. p. 284.

${ }^{8}$ Foreign policy was heatedly discussed of course and left-wingers like Konni Zilliacus and trade union leaders such as Frank Foulkes of the ETU accused Britain and America of threatening the Soviet Union with war. See Labour Party Annual Conference Report (London, Labour Party, 1947), pp. 106, 160-161, its report for 1948, p. 185 and the TUC Annual Report (London, TUC, 1946), pp. 469, 435, 473. 
${ }^{9}$ Denis Healey, Time of My Life (London, Penguin, 1990), p. 234.

${ }^{10}$ H. G. Wells, The Shape of Things to Come (London, J. M. Dent, 1993). See 'Book the Second', part 10, 'The Raid of the Germs'. Michael Foot, a Wells biographer, quoted passages from The World Set Free in his 1999 analysis of the India-Pakistan nuclear rivalry and the fin de siecle nuclear landscape, adding that "no book about the bomb is complete without him." Michael Foot, Dr Strangelove, I Presume (London, Victor Gollancz, 1999), p.19.

${ }^{11}$ Michael Coren, The Invisible Man: The Life and Liberties of H. G. Wells (London, Bloomsbury, 1994), p.130.

${ }^{12}$ Richard Rhodes, The Making of the Atomic Bomb (London, Penguin, 1988), p.28.

${ }^{13}$ Spencer R. Weart \& Gertrud Weiss Szilard (eds.) Leo Szilard: His Version of the Facts (Cambridge, Mass., MIT Press, 1978), p.53.

${ }^{14}$ See Jim Baggott, Atomic: The First War of Physics and the Secret History of the Atom Bomb, 1939-49 (London, Icon Books, 2009), pp.252-3.

${ }^{15}$ Plebs did. See the issue for September 1945, p.101.

${ }^{16}$ J. H. Oldham writing in the Christian Newsletter, 22 August 1945, p.7.

${ }^{17}$ Ibid. p.3.

18 Ibid. p.6.

${ }^{19}$ Christian Newsletter, 3 October 1945, editorial, p.1.

${ }^{20}$ Quoted by Maurice Goldsmith, Sage: A Life of J. D. Bernal (London: Hutchinson, 1980), p.132.

21 See Ronald W. Clark, JBS: The Life and Work of J. B. S. Haldane (London: Hodder and Stoughton, 1968), p.189.

22 J. D. Bernal, 'New Frontiers of the Mind', The Nation, September 1945, reproduced in J. D. Bernal, The Freedom of Necessity (London: Routledge and Kegan Paul, 1949), pp.314-320, at p.314

23 Ibid.

${ }^{24}$ Ibid. p.320.

${ }^{25}$ Quoted by Ivor Montagu, ‘The Peacemonger’, in B. Swann and F. Aprahamian, (eds.), J. D. Bernal: A Life in Science and Politics (London: Verso, 1999), p.217. ${ }^{26}$ Sir Charles Grant Robertson, 'World, Nations and Atom', The Observer, 9 December 1945. 
${ }^{27}$ E. L. Woodward, Some Political Consequences of the Atomic Bomb (Oxford, Oxford University Press, November 1945).

${ }^{28}$ Ibid.

${ }^{29}$ Arguments that were best expressed in J. D. Bernal, The Social Function of Science (London: George Routledge, 1939).

${ }^{30}$ The speech was also published in Left News, June 1946 and reproduced in Freedom of Necessity, pp.321-7.

${ }^{31}$ Ibid. p.322.

${ }^{32}$ Ibid. p.324

33 Ibid. pp.326-7

34 J. D. Bernal, BBC broadcast 'Challenge of our Time Series’, 31 March 1946, reproduced in Freedom of Necessity, pp.85-91, at p.90.

${ }^{35}$ David McCullough, Truman, (New York, Simon \& Schuster, 1992), pp.515-16.

${ }^{36}$ Baggott, Atomic, pp.362-7.

${ }^{37}$ Ibid. p.389.

${ }^{38}$ See Bertrand Russell, The Practice and Theory of Bolshevism (London, Allen and Unwin, 1920).

${ }^{39}$ Bertrand Russell, letter to Gamel Brenan, 1 September 1945, cited in Nicholas Griffin (ed.), The Selected Letters of Bertrand Russell: The Public Years, 1914 - 1970 (London, Routledge, 2001), p.410 [entry 469].

${ }^{40}$ Ray Monk, Bertrand Russell: The Ghost of Madness 1921-1970 (London, Vintage, 2001), pp.297-8.

41 'The Bomb and Civilisation’, Forward 39, 43, August 1945.

42 Ibid.

${ }^{43}$ Monk, Bertrand Russell: The Ghost of Madness, pp.298-305

${ }^{44}$ Russell to Einstein, 24 November 1947 in Griffin (ed.) The Selected Letters, p.423 [entry 479].

${ }^{45}$ Russell to Brenan, 1 September 1945 in Griffin (ed), p.410.

${ }^{46}$ Russell to Einstein, 24 November 1947 in Griffin (ed.), p.423.

${ }^{47}$ See Tribune 17 October 1947, p.3; 30 January 1948, p.3; 5 March 1948, p.8; 12 March 1948, p.11; and the editorials of 19 and 26 March and 23 April 1948.

${ }^{48}$ Russell to Walter Marseilles, $5^{\text {th }}$ May 1948 in Griffin (ed.), p.429 [entry 482]. 
${ }^{49}$ Monk, The Ghost of Madness, p. 302.

${ }^{50}$ Russell to Marseilles, in Griffin (ed.), p. 429.

${ }^{51}$ Monk, The Ghost of Madness, pp. 297-304; R. K. Perkins, 'Bertrand Russell and

Preventive War', in Russell, the Journal of the Bertrand Russell Archives, 14, winter 1994-95, pp. 135-53.

52 Bertrand Russell, 'Resisting Russia', The Observer, 28 November 1948, p.3.

${ }^{53}$ Kingsley Martin, 'London Diary’, The New Statesman, 18 November, 1950, p.449;

Russell's reply was published under the title 'Lord Russell and the Atomic Bomb', The New Statesman, 21 April 1951.

${ }^{54}$ Quoted in ibid, p.70.

${ }^{55}$ K. Zilliacus, I Choose Peace (London, Penguin Books, 1949), pp. 96-7.

${ }^{56}$ P. M. S. Blackett, Military and Political Consequences of Atomic Energy (London, Turnstile Press, 1948), pp. 126-7.

${ }^{57}$ Ibid. pp. 143-44.

${ }^{58}$ George Orwell, 'World Affairs, 1945', Junior 1945, in Peter Davison (ed.), The Complete Works of George Orwell: Vol. XVII I Belong to the Left, 1945 (London, Secker \& Warburg, 1998), entry 2708, pp.230-31.

${ }^{59}$ Ibid p.233.

${ }^{60}$ George Orwell, 'London Letter', Partisan Review, Fall 1945, ibid, entry 2719, p.249.

${ }^{61}$ George Orwell, 'Pacifism and Progress', Manchester Evening News, 1 February 1946, in Peter Davison (ed.), The Complete Works of George Orwell: Vol. XVIII Smothered Under Journalism, 1946 (London, Secker \& Warburg, 1998), entry 2878, p.67.

${ }^{62}$ George Orwell, 'Review of The Revolution in Warfare by B. H. Liddell Hart', Manchester Evening News, 4 April 1946 in ibid, entry 2960, pp.220-22.

${ }^{63}$ George Orwell, 'You and the Atom Bomb', Tribune, 19 October 1945, in Davison (ed.), Complete Works Vol. XVII, entry 2770, p.320.

${ }^{64}$ Ibid, p.321.

${ }^{65}$ George Orwell, 'What is Science?', Tribune, 26 October 1945, in Davison (ed.), Complete Works Vol. XVII, entry 2771, p.326. Scientists themselves were said to be alarmed at the encroaching secrecy which nuclear physics had unleashed on them all. 
See 'Secrecy in Science’, Civil Liberty (quarterly journal of the National Council for Civil Liberties), February-March 1947, p.1.

${ }^{66}$ Socialist scientists like Bernal had been utterly committed to the war effort from its onset and Bernal himself served with such distinction that the US government awarded him the Order of Freedom with Bronze Palms. When Orwell produced a series in 1942 for the BBC’s Indian Service on 'Science, Capitalism and Fascism' Marxist scientists such as Bernal were featured in it. But in the context of the Cold War, he found Bernal's emphasis on the 'social function of science' pernicious. It now represented evidence of a moral relativism in the service of totalitarianism. Michael Polanyi and Arthur Koestler added their own contributions to the denunciation of 'Bernalism' in the course of what became a public debate, given salience by Bernal's support for the Soviet agronomist and charlatan Trofim Lysenko, when scientific dissent from Lysenko's theories was formally outlawed in the USSR in 1948 . See Gary Werskey, The Visible College: A Collective Biography of British Scientists and Socialists of the 1930s (London: Allen Lane, 1978), pp.262, 267, 2869.

${ }^{67}$ George Orwell, ““Old George's Almanac" by Crystal-Gazer Orwell', Tribune, 28

December 1945, in Davison (ed.), Complete Works Vol. XVII, entry 2829, p.460.

${ }^{68}$ George Orwell, 'London Letter', Partisan Review, Summer 1946, in Davison (ed.), Complete Works Vol. XVIII, entry 2990, p.288.

${ }^{69}$ James Burnham, The Struggle for the World (New York, The John Dzy Company, 1947), p.5.

${ }^{70}$ George Orwell, 'Burnham's View of the Contemporary Struggle', The New Leader, 29 March 1947, in Peter Davison (ed.), The Complete Works of George Orwell: Vol. XIX It Is What I Think, 1947-1948 (London, Secker \& Warburg, 1998), entry 3204, pp. 96-106, p.98.

${ }^{71}$ Ibid, p.99.

72 Ibid.

${ }^{73}$ Ibid, p.103.

${ }^{74}$ George Orwell, 'Toward European Unity', Partisan Review, July-August 1947, in

Davison (ed.), Complete Works Vol. XIX, entry 3244, p.163.

75 Ibid. 
${ }^{76}$ Ibid.

${ }^{77}$ Christopher Hitchens, Orwell's Victory (London, Penguin, 2003), pp.83-88.

${ }^{78}$ Bernard Crick, George Orwell: A Life (London, Secker \& Warburg, 1980).

${ }^{79}$ George Orwell, 'In Defence of Comrade Zilliacus', unpublished, written summer 1947, in Davison (ed.), Complete Works Vol. XIX, entry 3254, p.182.

${ }^{80}$ Lawrence Freedman, Evolution of Nuclear Strategy, (London, Palgrave 1989) p.56.

${ }^{81}$ George Orwell, 'George Gissing', $1^{\text {st }}$ published in the London Magazine, June 1960, in Davison (ed.), Complete Works Vol. XIX, entry 3406, p.347.

${ }^{82}$ Letter to David Astor, 9 October 1948, ibid, entry 3467, p.451.

${ }^{83}$ Letter to Julian Symonds, 29 October 1948, ibid, entry 3481, p.462.

84 Ibid.

${ }^{85}$ Daily Worker, 17 July 1948.

${ }^{86}$ Daily Worker, 24 January 1948.

${ }^{87}$ See John Callaghan, Cold War, Crisis and Conflict: the history of the Communist Party of Great Britain, 1951-68 (London: Lawrence and Wishart, 2003) and 'The Cultural Cold War and anti-Americanism, 1947-91', in Brendon O’Connor (ed.), Anti-Americanism: History, Causes and Themes - Volume 2 Historical Perspectives (Oxford: Greenwood, 2007), pp.177-202.

${ }^{88}$ Quoted in the Daily Herald, 1 April 1949, p.1. This argument was furiously refuted by Michael Foot who argued that Churchill completely missed the point; the Soviet appeal was 'based on a monstrous delusion about the real conditions in the USSR and partly on the promise that it can bring a new and better social order'. Thus the war that mattered was a war for minds. Daily Herald, 8 April 1949.

${ }^{89}$ George Orwell, 'Why I Write', Gangrel, Summer 1946, in Davison (ed.), Complete Works Vol. XVIII, entry 3007, p.319.

${ }^{90}$ Orwell, 'Burnham’s View of the Contemporary Struggle’, New Leader, 29 March 1947.

91 'The Russian Atomic Bomb’, Tribune, 30 September, 1949, editorial p.5.

${ }^{92}$ New Statesman and Nation, 26 November 1949, p.1.

${ }^{93}$ See Collier's magazine, special issue 'Russia's Defeat and Occupation, 1952-60', 27 October 1951. Contributors included Arthur Koestler, J. B. Priestley, Walther 
Reuther, Ed Murrow, Walter Winchell and Stuart Chase. Priestley, famously, would help to found CND in 1958. 